\title{
PWWP2A wt Allele
}

National Cancer Institute

\section{Source}

National Cancer Institute. PWWP2A wt Allele. NCI Thesaurus. Code C122891.

Human PWWP2A wild-type allele is located in the vicinity of $5 q 33.3$ and is approximately $58 \mathrm{~kb}$ in length. This allele, which encodes PWWP domain-containing protein 2A, may be involved in binding to other proteins or to DNA. 